\title{
KERANGKA HUKUM NEGARA DALAM MENGATUR AGRARIA DAN KEHUTANAN INDONESIA ${ }^{1)}$
}

\author{
Oleh : Hendra Sukarman, S.H., S.E., M.H. ${ }^{2}$
}

\begin{abstract}
ABSTRAK
Indonesia adalah negara kepulauan terbesar di dunia, populasi keseluruhannya terbesar dan luas tanah kira-kira enam kali ukuran Inggris. Tanah dan semua sumber daya alam secara hukum dikuasai oleh negara. Selama dua dekade terakhir, sistem dual administrasi tanah telah muncul dimana sekitar $39 \%$ dari lahan berada dalam yurisdiksi Badan Pertanahan Nasional (BPN) dan 61\% dikelola oleh Departemen Kehutanan (Dephut). Menyadari konflik yang luas atas tanah di dalam area hutan dan implikasi untuk keamanan pangan, makalah ini mengeksplorasi asal-usul dualitas ini dan tantangan apakah ada dasar hukum untuk Departemen Kehutanan untuk mengelola lahan.
\end{abstract}

\section{ABSTRACT}

Indonesia is the largest archipelago in the world, the forth largest population and a land area approximately six times the size of the United Kingdom. Land and all natural resources are by law controlled by the State. Over the past two decades, a dual system of land administration has emerged where approximately $39 \%$ of lands are within the jurisdiction of the Land Agency (BPN) and $61 \%$ is administered by the Department of Forestry (Dephut). Recognizing the broad conflict over land inside the Forest area and implications for food security, this paper explores the origins of this duality and challenges whether there is a legal basis for the Department of Forestry to administer lands.

\section{Latar Belakang}

Di Indonesia segala kekayaan alam termasuk tanah, sumber daya alam hayati dan air dikuasai oleh negara. Hal ini ditegaskan dalam Undang-Undang Dasar 1945. Sangat jelas bahwa pemerintah mewakili negara, bertanggung jawab menjamin semua kekayaan alam tersebut dikelola dengan baik dengan menjamin kekayaan yang di hasilkan digunakan sebaik-baiknya untuk meningkatkan kesejahteraan seluruh rakyat Indonesia.

Setelah Konstitusi, peraturan paling penting yang berkaitan dengan pengelolaan dan distribusi manfaat sumber daya alam yaitu TAP MPR IX tahun 2001 tentang Pembaruan Agraria dan Pengelolaan Sumber Daya Alam. Hal ini secara umum dapat dilihat sebagai suatu pencapaian dan pernyataan eksplisit MPR, dimana yang paling penting dan dibutuhkan oleh

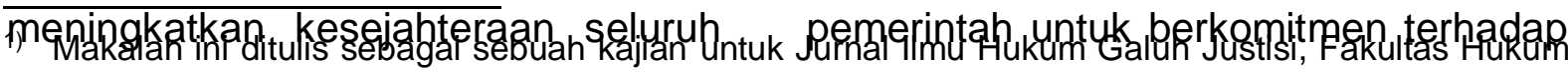

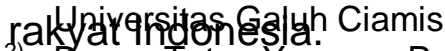
2) Dosen Tetap Yayasan Pendidikan Galuh Ciamis pembaruan pengelolaan sumber daya alam dan pembaruan agraria. 
pemerintah untuk berkomitmen terhadap pembaruan pengelolaan sumber daya alam dan pembaruan agraria. Hal ini mengharuskan Negara (termasuk pemerintah) untuk mengkaji, mencabut dan merevisi semua peraturan perundang-undangan mengenai tanah dan sumber sumber agrarian lainnya dan pada saat yang sama menyelesaikan konflik agraria yang ada saat ini secara adil dan lestari. Tap MPR ini telah menjadi alat yang paling ampuh dalam proses reformasi untuk penyempurnaan peraturan perundang undang agraria di Indonesia (Prof Arie Sukanti, TAP No.I/2003 memperkuat TAP No.IX/2001 dengan mengklasifikasikan TAP MPR IX/2001 tentang Pembaruan Agrarian dan Pengelolaan Sumber Daya Alam sebagai sumber hukum hingga semua isi TAP No.IX/2001 diterjemahkan ke dalam peraturan perundang-undangan. Demikian pula TAP MPR Nomor V/2003 tentang saran kepada Lembaga Tinggi Negara, meminta agas segera merealisasikan TAP MPR No IX/2001 ini).

Undang-undang Pokok Agraria Nomor 5 tahun 1960 dan Undangundang Kehutanan Nomor 41 tahun 1999 merupakan dua perundangundangan paling penting yang dalam hirarki perundangan tanah dan sumber daya alam menduduki urutan kedua setelah Konstitusi. Kedua aturan tersebut secara langsung mengatur pengelolaan dan distribusi sumber daya alam. Tulisan ini meninjau hubungan antar peraturan perundang-undangan dan responsnya terhadap TAP MPR No. IX/2001 tentang Pembaruan Agraria dan Pengelolaan Sumber Daya Alam. Dikemukakan analisa hukum mengenai lingkup Undang-Undang Kehutanan dan peran pemerintah dalam mengatur sumber daya hutan.

Keadaan pengelolaan sumber daya alam di Indonesia saat ini sangat beragam. Di sepanjang berjuta-juta hektar masyarakat setempat menanam dengan produktif hutan pohon pohonan, buah-buahan, getah-getahan, kopi, coklat dan seringkali mencampurkan pohon kayu-kayuan kedalam "agroforests" (Foresta, Kusworo, Michon, Djatmiko 2000; Suhardjito (ed), 2000; Jurnal Hutan Rakyat 2002). Hutan-hutan ini menyediakan banyak jasa lingkungan, menyerupai hutan alam namun dengan sedikit lebih rendah dalam kandungan keanekaragaman hayatinya dibandingkan dengan hutan alam. Secara garis besar situasi hutan alam Indonesia hanya dapat digambarkan sebagai sebuah krisis, namun banyak masyarakat yang juga melindungi hutan-hutan alam yang 
tersisa di dalam bentang alamnya, kadang kala dengan kerjasama dengan pemerintah setempat termasuk petugas kehutanan maupun dilakukan secara swasaya (Tari Dala \& Adi Jaya, 2002; Roshetko, Mulawarman, Santosa, Oka (ed) 2002 ; Warsi 2000). Akan tetapi, angka kerusakan hutan per tahun yang mencapai 1 juta hektar, tetap konsisten selama 10 tahun terakhir ini dan kapasitas terpasang dari industri perkayuan tetap jauh melebihi apa yang ditetapkan sebagai batas jatah tebang tahuanan yang lestari. (Badan Planologi Kehutanan, 2003) Analisa terakhir Departemen Kehutanan, Jatah Tebang Tahunan tahun 2002 menurun tajam hingga hampir 10 juta kubik $\mathrm{m}^{3}$ kayu sementara kayu yang masuk pada indutri tahun tersebut melebihi 50 juta kubik $\mathrm{m}^{3}$---terlihat 4 kali lebih besar dari kayu dengan sumber legal dan illegal. (Josef Litski 2004; Brown 2003). Dengan data saat ini, tampaknya produksi hutan alam Indonesia akan habis pada akhir dekade ini dan banyak kawasan hutan konservasi akan terancam bahaya atau bahkan hilang sama sekali.

Konflik antara masyarakat setempat yang mengklaim hak atas tanah dan sumber daya yang ada di kawasan hutan dan industri kehutanan serta petugas kehutanan telah mencuat secara konsisten selama 15 tahun teakhir. (Fern 2001; Dephut-Dinas Kehutanan Kab. Garut 2004; Kusworo A, 2000). Ketidakjelasan penguasaan baik oleh masyarakat maupun dari pihak industri telah menyebabkan penurunan fungsi tanah dan hutan serta seringkali diikuti dengan kekerasan. Inti dari berbagai masalah ini adalah ketidakjelasan "aturan main" seperti yang disebutkan oleh Departemen Kehutanan. Departemen ini menyatakan memiliki kewenangan atas daratan Indonesia namun tidak dapat mengelola wilayah yang begitu luas dan memberikan kepastian penguasaan dan pengelolaan yang dibutuhkan baik bagi masyarakat setempat maupun bagi industri kehutanan.

Kebingungan dan ketidaksetujuan akan siapa yang seharusnya menguasai atau memiliki hutan dan kawasan hutan di Indonesia semakin meningkat dan dilihat sebagai penyebab utama oleh banyak kalangan (meskipun tidak semuanya) sebagai, kegagalan Indonesia untuk mengelola kawasan hutanya. Asal dari kebingungan ini, bagian terbesar terletak pada pengertian dasar atas apa dan dimana hutan Indonesia serta apa dan dimana kewenangan Departemen Kehutanan. Pada waktu yang bersamaan, konflik atas tanah dan sumber daya alam yang diakibatkan oleh ketidakjelasan tanah 
negara dengan tanah rakyat akan tetap ada jika tidak ada usaha serius untuk merasionalisasikan kawasan hutan negara melalui strategi prioritas yang jelas.

TAP MPR No.IX tahun 2001 tentang Pembaruan Agraria dan Pengelolaan Sumber Daya Alam secara eksplisit menyebutkan bahwa peraturan perundang undangan yang saling bertentangan dan berhubungan dengan tanah dan penguasaan sumber daya lainnya oleh department/instansi sektor haruslah dihentikan, karena pertentangan ini menciptakan kemiskinan dan penurunan sumber daya alam. Peraturan perundang-undangan ini harus direvisi, dicabut atau diubah menggunakan pendekatan holistik. Pada saat yang sama konflik harus diselesaikan melalui proses yang adil. undangan tgl 14 November 2003 di UGM-Yogyakarta, semua departemen /instansi pemerintah yang berhubungan dengan tanah dan sumber daya alam (termasuk hutan) telah bertemu dan menyepakati bahwa revisi UndangUndang Pokok Agraria Nomor 5 tahun 1960 harus menciptakan kerangka yang menaungi sistem penguasaan atas tanah maupun sumber daya alam lainnya secara lebih baik dan menghentikan pendekatan sektoral. Beberapa Undang undang tercatat sebagai undang undang "payung" yang menjadi rujukan /referensi yaitu UndangUndang Pokok Agraria dan UndangUndang Tata Ruang., perlu direvisi, demikian juga Undang-undang Sumber Daya Alam perlu segera dibuat. (catatan dari pertemuan : Penjabaran Prinsip Prinsip TAP MPR IX/2001 dan Upaya Harmonisasi Peraturan PerundangUndangan di Bidang Sumber Daya Agraria. UGM, 14 November 2003 Yogyakarta).

Akan tetapi, Persepsi yang umum dan berkali kali ditemui yaitu 120 juta hektar wilayah Indonesia, 61\% tanah daratanya adalah "tanah hutan" yang dimiliki dan dikelola oleh Departemen Kehutanan. Hal ini termasuk padang rumput, daerah pertanian, sebagian wilayah desa, agroforest, termasuk juga wilayah yang luas dari hutan primer dan hutan sekunder. secara garis besar situasi hutan alam Indonesia hanya dapat digambarkan sebagai sebuah krisis Bagaimana Departemen Kehutanan mengklaim kewenangannya, dibahas dalam paper ini demikian pula implikasinya bagi masyarakat setempat, konflik penguasaan tanah, dan perlindungan hutan alam.

Analisa yang tepat tentang kewenangan kehutanan dan pengelolaan sumber daya alam secara garis besar harus diawali dengan 
mengkaji Undang-undang Pokok Agraria Nomor 5 tahun 1960 (UUPA). Sisi yang tepat untuk mengawalinya adalah dengan pandangan ahli hukum pertanahan Prof. Boedi Harsono yang pada tahun 1984 menjelaskan (Boedi Harsono, 1997) :

\begin{tabular}{|c|}
\hline $\begin{array}{l}\text { pandangan hukum } \\
\text { tanahan, sebidang tanah } \\
\text { g tumbuh hutan diatasnya, } \\
\text { ggusasaan tanahnya diatur } \\
\text { h Hukum Tanah (UUPA). } \\
\text { ngelolaan haknya diberikan }\end{array}$ \\
\hline
\end{tabular}

Di sisi lain Prof. Maria Sumardjono (2001) pada saat proses revisi Undang Undang Pokok Kehutanan Nomor 5 Tahun 1967 mengatakan bahwa :
Ruang lingkup (Rancangan) Undang-undang Kehutanan seharusnya dibatasi pada penagturan tentang pemanfaatan sumber daya hutan. Penentuan kawasan hutan diperlukan untuk membatasi luasnya kewenangan pengelolaan pemanfaatan sumber daya htan dan tidak dimaksud untuk membrikan wewenang untuk mengatur tentang penguasaan tanah di dalam kawasan hutan tersebut. Pemberian hak untuk memanfaatkan kawasan hutan (HPH \& HPHTI) dilakukan oleh Departemen Kehutanan, sedangkan pemberian hak atas tanah, misalnya HGU dll dilakukan oleh BPN. (Sumardjono, 2001).

Dengan pemahaman dua argumentasi pakar hukum pertanahan ini maka Departmen Kehutanan hanya dapat memberikan hak pengusahaan dan hak pemungutan hasil hutan, sedangkan segala proses yang berkaitan dengan penguasaan atas tanah dilakukan oleh instansi lain (BPN). Maka penataan batas kawasan hutan tidaklah menjadi batasan untuk tidak menggunakan Undang Undang Pokok Agraria Nomor 5 tahun 1960, sebagaimana lazim dipraktekan saat ini.

\section{Undang-Undang Pokok Agraria Nomor 5 Tahun 1960 (UUPA)}

Undang-undang ini salah satunya adalah mengatur 197 juta hektar wilayah daratan Indonesia. Undang undang ini 
menuntun pemerintah dalam pengakuan dan pemberian 7 jenis hak atas tanah dan tambahan 3 jenis hak pemanfaatan sumber daya alam. (Pasal 16 BAL dijelaskan; hak milik, hak guna usaha, hak guna bangunan, hak pakai, hak sewa, hak membuka tanah, hak memungut hasil hutan, hak hak yang tidak termasuk diatas yang akan ditetapkan dengan undang-undang serta hak hak yang sifatnya sementara). Hak yang paling kuat dan paling penuh dari semua jenis tersebut adalah hak milik. Diantara berbagai hak atas tanah, maka yang telah diatur lebih lanjut adalah Hak Guna Usaha, Hak Guna Bangunandan Hak Pakai (Peraturan Pemerintah Nomor 40 tahun 1996) Peraturan Pemerintah Nomor. 24 tahun 1997 tentang Pandaftaran Tanah mengatur konsep dan prosedur untuk pengakuan atau pemberian berbagai jenis hak atas tanah. Dalam peraturan ini tanah dibagi ke dalam 2 jenis yaitu tanah bekas hak adat, yaitu hak lama yang telah diakui keberadaanya jauh sebelum adanya UUPA serta hak lainnya diberikan dengan Aturan yang lebih rinci yaitu Hak Guna Bangunan, Hak Guna Usaha atau Hak Pakai berdasarkan permohonan hak dengan subjek hak atas tanah, yang terdiri dari orang per-orang dan badan hukum. Akan tetapi UUPA masih meninggalkan banyak pekerjaan rumah, dalam

pembentukan

peraturan

perundang undangan yang merupakan peraturan pelaksanaan UUPA. Pada umumnya UUPA tidak dilengkapi dengan pemikiran yang tuntas terhadap peraturan pelaksanaannya. Diperlukan upaya terus menerus untuk melakukan penemuan hukum dalam rangka pembangunan hukum tanah yang bertanggung jawab (Sumardjono, 2001).

Sementara UUPA dan banyak peraturan pengelolaan sumber daya alam lainnya memberi banyak perhatian kepada pengakuan atas Hak Ulayat (hak Adat), akan tetapi sedikit sekali peluang untuk pengakuan hak adat tersebut dan lebih sedikit sekali kemauan politik untuk mengakuinya. Satu pengecualian yang penting yaitu prosedur untuk pengakuan hak ulayat (atau dengan nama lain) bagi masyarakat hukum adat, diterbitkan pada tahun 1999 berdasar pada keputusan Menteri Negara Agraria/ Kepala BPN yang mengatur pedoman untuk penyelesaian masalah hak ulayat masyarakat hukum adat, dimana kewenangan pengakuan keberadaan masyarakat adat diberikan kepada pemerintah daerah kabupaten.melalui peraturan daerahnya (Peraturan Menteri Agraria,/Kepala BPN Nomor 5, 1999 tentang pedoman penyelesaian masalah hak ulayat masyarakat hukum adat; (Lihat pula Sumardjono 2003 ; 
Sumardjono 2004a ; Sumardjono 2004b berkaitan dengan kedudukan Hak Ulayat). Peraturan ini diterbitkan, antara lain karena tekanan politik langsung dari AMAN, (Aliansi Masyarakat Adat Nusantara) dalam Konferensi Masyarakat Adat Nusantara I di tahun 1998, akan tetapi belum banyak usaha serius dari berbagai kabupaten untuk mengunakan kebijakan ini sebagai alat penyelesaian maslaha tuntutan masyarakat adat atas tanah dan sumber daya alam lainnya (Salah satu inistiatif pemerintah daerah dalam mengakomodir hak hak masyarakat adat melalui pengakuan keberadaan masyarakat adat antara lain; Peraturan Daerah Kabupaten Lebak Nomor 32 tahun 2001 tentang Perlindungan Atas Hak Ulayat Masyarakat Baduy).

\section{Undang-undang Kehutanan Tahun 1999}

Undang-undang Kehutanan tahun 1999 merupakan salah satu undangundang yang dikeluarkan setelah masa pemerintahan Suharto atau dikenal dengan periode reformasi. Undangundang ini memberi kewenanangan pada pemerintah melalui Departemen Kehutanan untuk menentukan dan mengelola Kawasan Hutan Indonesia. Dalam undang-undang tersebut tidak tercantum kewenangan Departemen
Kehutanan atas penerbitan jenis-jenis hak penguasaan atas tanah yang diatur oleh UUPA. Bahkan secara hukum dapat dikatakan tepat bahwa "tanah hutan" tidak terdapat di Indonesia sebagai suatu definsi hukum. Istilah tanah hutan bukanlah istilah resmi bahasa Indonesia juga bukan pernyataan yang digunakan dalam perdebatan kehutanan dan pengelolaan hutan. Istilah yang resmi yaitu kawasan hutan yang diterangkan sebagai "suatu kawasan yang ditunjuk dan atau ditetapkan oleh pemerintah untuk dipertahankan sebagai hutan". (Kata "Kawasan" sering digunakan dalam perencanaan pembangunan dan seringkali diartikan sebagai wilayah, daerah atau lingkungan seperti "Kawasan Pariwisata" untuk kepariwisataan atau "Kawasan Industri" sebagai daerah industri dan "Kawasan Hutan" sebagai wilayah hutan. Tidak ada hubungan hukum dengan kepemilikan tanah). Maka secara hukum kawasan hutan dapat dibagi menjadi 2 bagian yaitu :

- Kawasan Hutan Negara, yaitu wilayah dimana pemerintah (Departemen Kehutanan) telah menetapkan bahwa tidak ada hak privat (private rights) atas tanah tersebut dan; 
- Hutan Hak, yaitu wilayah dimana tanahnya dan yang hutan diatasnya dibebani hak privat lainnya (private rights).

Berikut detail dari masing-masing 3 istilah tersebut, asal dan kegunaan :

\section{Kawasan Hutan}

Kawasan hutan (bentuknya bukan namanya) pertama kali diperkenalkan pada masa kolonial ketika sebagian besar besar wilayah Jawa dan sebagian kecil wilayah Sumatra ditatabas dan ditetapkan sebagai Kawasan Hutan . Usaha-usaha pertama-tama dilakukan oleh Jawatan Kehutanan pada awal abad ke-19 dengan tujuan mengontrol tanah, pohon-pohonan dan tenaga kerja hutan. Peraturan perundang-undangan masa itu berusaha-usaha untuk memperluas kontrol atas kawasan hutan ini tampak hingga hari ini, dimana hampir seperempat wilayah Jawa ditetapkan sebagai kawasan hutan dan hamper seluruhnya berada di bawah kontrol BUMN kehutanan Perum Perhutani (Peluso (1992) hal. 45).

Kawasan Hutan digunakan sebagai istilah resmi dalam Undangundang Pokok tentang Kehutanan tahun 1967 dan menjadi basis kewenangan Departemen Kehutanan dalam Undangundang Kehutanan 1999. Prosedur penentuan kawasan hutan secara aktual dapat dilacak dalam Peraturan Pemerintah tentang Perencanaan Kehutanan yang ditandatangani oleh Presiden Suharto pada tahun 1970 (PP33/1970 tentang Perencanaan Hutan). Namun sangat penting untuk dicatat bahwa jauh sebelum itu pemerintah telah memberikan konsesi pengusahaan hutan di luar Jawa, bahkan sebelum Undang-undang Kehutanan tahun 1967 diterbitkan. Konsesi-konsesi tersebut terletak pada hutan alam yang pada saat itu belum ada persyaratan hukum atau persyaratan pengelolaan untuk menentukan apakah wilayah konsesi tumpang tindih dengan hak-hak masyarakat setempat. Tanah-tanah di dalam dan sekitar wilayah konsesikonsesi tersebut berada di bawah kewenangan Departemen Agraria dan "belum terdaftar" seperti halnya sebagian besar tanah-tanah di Indonesia saat ini.

Peraturan Pemerintah Nomor 33 tahun 1970 tentang Perencanaan Hutan, memberi kewenangan kepada Departeman Pertanian (yang pada saat itu menginduki Dirjen Kehutanan) untuk menetapkan manakah yang termasuk kawasan hutan negara dan yang bukan. Aturan yang digunakan untuk mengukuhkan kawasan hutan 
dikeluarkan pada tahun 1974 (Surat Keputusan Menteri Kehutanan No.85/74tentang Pedoman Penataan Batsa Kawasan Hutan) dan pada pertengahan tahun 80an hampir tiga perempat dari keseluruhan tanah Indonesia ditunjuk oleh Departemen Kehutanan yang baru sebagai Kawasan Hutan. Proses tersebut dilaksanakan oleh Departemen sebagai Tata Guna Hutan dengan Kesepakatan (TGHK). Hal itu dilakukan melalui data survei dan data peta vegetasi berdasarkan penginderaan jauh dan ditentukan oleh proses penilaian biofisik dengan kriteria scoring yang rumit dan mengabaikan kedaan kriteria sosial. Kategori hutan dibuat dengan rekapitulasinya sebagai berikut :

Tabel 1.

Penunjukan Kawasan Hutan Indonesia berdasarkan TGHK

\begin{tabular}{|c|l|r|}
\hline No & \multicolumn{1}{|c|}{ Fungsi Hutan } & \multicolumn{1}{|c|}{$\begin{array}{c}\text { Luas Wilayah } \\
(\mathbf{H a})\end{array}$} \\
\hline 1 & Kawasan Konservasi & 19.152 .885 \\
\hline 2 & Hutan Lindung & 29.649 .231 \\
\hline 3 & Hutan Produksi Terbatas & 29.570 .656 \\
\hline 4 & Hutan Produksi Tetap & 33.401 .655 \\
\hline 5 & Hutan Produksi Konversi & 30.000 .000 \\
\hline & T O T A L & $\mathbf{1 4 1 . 7 7 4 . 4 2 7}$ \\
\hline
\end{tabular}

Seperti yang terlihat ternyata tingkat kesepakatan atau penerimaan para pihak tidak setinggi ketika pertama kali diprediksi oleh Departemen Kehutanan. Pemerintah daerah seringkali menentang batas dan kekakuan

penggunaan

ruang

berhadapan dengan pilihan-pilihan pembangunan, yang dibatasi oleh fungsi hutan. Antara tahun 1999 dan 2001 berbagai kompromi dicapai melalui proses perencanaan ruang tingkat provinsi (RTRWP) dan saat ini sah bila dikatakan bahwa kawasan hutan Indonesia merupakan hasil dari sinkronisasi TGHK dan RTRWP (Kecuali untuk 3 propinsi yaitu Kalimantan Tengah, Sumatera Utara dan Riau dimana kompromi RTRWP dan TGHK belum tercapai (Statistik Kehutanan Eksekutif 2003).

Tabel 2.

Penunjukan Kawasan Hutan Berdasarkan Paduserasi TGHK dan RTRWP

\begin{tabular}{|c|l|r|}
\hline No & \multicolumn{1}{|c|}{ Fungsi Hutan } & \multicolumn{1}{c|}{$\begin{array}{l}\text { Luas } \\
\text { Wilayah (Ha) }\end{array}$} \\
\hline 1 & $\begin{array}{l}\text { Kawasan Konservasi } \\
\text { (KSA/KPA/TB) }\end{array}$ & 20.500 .988 \\
\hline 2 & Hutan Lindung (HL) & 33.519 .600 \\
\hline 3 & $\begin{array}{l}\text { Hutan Produksi Terbatas } \\
\text { (HPT) }\end{array}$ & 23.057 .449 \\
\hline 4 & Hutan Produksi Tetap (HP) & 35.197 .011 \\
\hline 5 & $\begin{array}{l}\text { Hutan Produksi Konversi } \\
\text { (HPK) }\end{array}$ & 8.078 .056 \\
\hline \multicolumn{2}{|c|}{ T O T A L } & $\mathbf{1 2 0 . 3 5 3 . 1 0 4}$ \\
\hline
\end{tabular}

Sumber : Badan Planologi Kehutanan (2003).

Pemahaman kami bahwa wilayah seluas 120 juta hektar ini dapat diterima sebagai kawasan hutan yang dapat diterima (legitimate) berdasarkan kewenangan hukum Departemen Kehutanan untuk menentukan atau menunjuk kawasan hutan. (UndangUndang Kehutanan 41, Bab 1, paragraf 1, bagian 3). Namun hal ini bukan berarti 
bahwa dalam proses membatasi penggunaan lahan untuk kegiatan kehutanan di sebagian besar wilayah negara, hak-hak lokal berdasarkan peraturan lain dapat dilanggar, baik di wilayah yang ditentukan untuk menjadi.

Hutan Negara dan Hutan Milik/Hutan Rakyat (Posisi hukum yang tegas dapat digunakan dengan menekankan persyaratan pelibatan peran serta masyarakat dalam penentuan rencana tata ruang yang dijamin dalam Undang Undang Tata Ruang telah diabaikan dalam menetukan Kawasan Hutan). Terlihat nyata bahwa hasil-hasil proses perencanaan yang menggiring $61 \%$ wilayah daratan Indonesia diklasifikasikan sebagai kawasan hutan sungguh tidak sebanding dalam kualitasnya. Bagian yang luas seperti padang rumput dan pemukiman yang tidak termasuk dalam klasifikasi hutan menurut Undang-Undang Nomor 41 tahun 1999 tentang Kehutanan, dimasukan ke dalam kawasan hutan. Namun pada saat yang sama beberapa wilayah berhutan alam tidak termasuk ke dalam kawasan hutan. Sebagai tambahan menurut data Departemen Kehutanan sekitar 24 juta hektar kawasan hutan tidak ditumbuhi pohon sama sekali. (Badan Planologi Kehutanan (2002) seperti yang dijelaskan dalam Rasionalisasi Wilayah Hutan di Indonesia: Sebuah Kajian tentang Kondisi Sumber Daya Hutan dan Reformasi Hukum, World Agroforestry Center (2003)).

\section{Kawasan Hutan Negara}

Kawasan hutan hanya dapat secara resmi dinyatakan sebagai Kawasan Hutan Negara ketika sudah diketahui bahwa tidak ada hak lain atas tanah hutan tersebut berada (seperti hak yang diatur dalam Undang-Undang Pokok Agraria tahun 1960). Tujuan dari Undang- Undang Nomor 41 tahun 1999 tentang Kehutanan sangat jelas dan seringkali isinya saling berkontradiksi. UUK secara bias berganggapan bahwa Kawasan Hutan Negara sebagai seluruh wilayah yang digambarkan oleh TGHK/RTRWP dan tidak ada hak milik (private right) lagi diatasnya. Hak milik (Private rights) dijelaskan sebagai tanah bersertifikat yang dikeluarkan oleh BPN menurut UUPA (Dalam Peraturan perundang-undangan bidang kehutanan definisinya Hutan Negara dan Hutan Hak saling bertentangan, dalam prakteknya menyebabkan peraturan perundangan menjadi tidak jelas). Penjelasan Undang-Undang Kehutanan tahun 1999 jelas menyatakan bahwa pada prinsipnya seluruh wilayah yang sebelumnya dikuasai oleh Hukum Adat 
didalam Kawasan Hutan masuk ke dalam kategori Hutan Negara. Hal ini jelas sangat bertentangan dengan definisi Hutan Hak dalam UndangUndang Kehutanan tahun 1999 dan Peraturan Pemerintah Nomor 24 tahun 1997 tentang Pendaftaran Tanah dimana dengan disertai bukti, hak milik (private rights) dapat diakui atau diberikan sesuai dengan UUPA 1960. Untuk menjelaskan hal ini, 4 langkah proses detail penataan kawasan hutan dibentuk dan dikenal dengan hasilnya yaitu Berita Acara Tata Batas.

Hanya jika langkah keempat dan langkah terakhir telah selesai ditempuh, maka penandatanganan oleh Departemen Kehutanan yang menandai selesainya proses BATB dapat dilakukan, maka kawasan hutan yang statusnya belum jelas dapat dikategorikan sebagai Kawasan Hutan Negara. Pada akhir tahun 2003 Departemen Kehutanan telah sepenuhnya menetapkan 12 juta hektar dari Kawasan Hutan sebagai Kawasan Hutan Negara (Statistik Kehutanan; 2002). Angka tersebut mewakili 10\% dari keseluruhan Kawasan Hutan di Indonesia.

Dengan menandatangani BATB berikut yang melibatkan masyarakat secara adil dan benar- dimana masyarakat setempat menandatangani berita acara yang menjelaskan bahwa mereka tidak memiliki klaim atas tanah tersebut, setelah mendapatkan penjelasan atas konsekwesni hukumDephut dan BPN dengan menggunakan prinsip-prinsip UUPA, dapat mengkasifikasikan kawasan tersebut secara hukum sebagai Kawasan Hutan Negara.

Saat ini hanya hampir $10 \%$ dari daratan Indonesia telah terdaftar di bawah salah satu hak yang diatur dalam UUPA, dengan hanya sedikit dari hakhak tersebut merupakan hak milik (Thorburn, 2002). Tanah yang tersisa, lebih banyak tanah pertanian dan hutanhutan yang "tidak terdaftar". Tanahtanah tersebut digolongkan oleh BPN sebagai tanah yang dikuasai negara tapi bukan "Tanah Negara", sementara pemerintah belum menentukan apakah hak-hak atas tanah-tanah tersebut ada atau tidak, seperti yang diatur dalam PP No. 24 tahun 1997 tentang Pendaftaran Tanah. (Sumardjono, 2001, hal 63 \& hal 43). Sebagai hasilnya negara tidak dapat memberikan hak kelola atau hak pakai (bahkan jika menguasai tanah) atas wilayah-wilayah tersebut ,sampai hal tersebut diputuskan apakah pada tanah tersebut terdapat hak milik atau tidak. Hanya dengan cara menyelesaikan penataan batas kawasan hutan, Departemen Kehutanan baru 
dapat mengeluarkan izin pengusahaan/ pemanfaatan/ pemungutan atas kawasan hutan atau kepada mereka yang telah memiliki diakui hak-haknya dalam mengelola hutan (Boedhi Harsono; 1977:23).

Implikasinya kepada bidang kehutanan dan pertambangan cukup jauh. Hampir tanpa pengecualian izin industri eksplorasi sumber daya alam dan penggunaan lahan yang telah dikeluarkan atas tanah yang statusnya belum ditentukan oleh negara apakah dibebani hak milik atau tidak. Dalam kasus kehutanan, tanah-tanah yang statusnya belum diketahui jumlahnya telah mencapai 108 juta hektar atau hampir $90 \%$ dari kawasan yang diklaim sebagai Kawasan Hutan oleh Dephut.

\section{Kawasan Hutan Hak}

Jika hasil dari proses penetapan kawasan hutan selesai secara lengkap, seperti yang dijabarkan oleh Departemen Kehutanan- saat ini jumlahnya 10\% dari Kawasan Hutandapat diasumsikan sah secara hukum, sedangkan sisanya yang 90\% termasuk ketegori Kawasan Hutan Hak, atau wilayah hutan milik, sebelum terbukti sebaliknya.

Dapat dikatakan sah secara hukum memandang kedua wilayah; Kawasan Hutan Negara dan Kawasan
Hutan Hak berada di bawah kewenangan BPN atau lembaga yang bertanggungjawab atas pengurusan penguasaan atas tanah sesuai dengan UUPA. Dalam kasus Kawasan Hutan Negara, menurut UUPA tanah-tanah tersebut merupakan Tanah Negara sejak BATB menyatakan tidak ada hak hak lokal diatasnya. Sedangkan dalam kasus Kawasan Hutan Hak, hampir tanpa pengecualian, belum ditentukan ada tidaknya hak hak lokal dan tanahtanah ini tetap "belum terdaftar" sebagai wilayah yang ditetapkan Departeman Kehutanan sebagai Kawasan Hutan. "Tanah-tanah yang belum terdaftar" dikuasai oleh Negara namun secara teknis bukan "Tanah Negara".

Pasal 12 UUK mengizinkan Departemen Kehutanan untuk melanjutkan penataan gunaan kawasan hutan dengan menentukan fungsi hutan produksi, konservasi dan fungsi hutan lindung mengingat proses penetapan kawasan hutan akan membutuhkan waktu yang lama. Namun demikian penatagunaan kawasan hutan tidak dapat dilanjutkan dengan proses apapun (termasuk pemberian ijin ijin diatasnya) sebelum ada status pengusaaannya ditentukan melalui proses pendaftaran tanah menurut PP No.24 tahun 1997 tentang Pendaftaran Tanah atau aturan lain yang diatur dalam UUPA atau 
melalui proses penataan batas kawasan hutan yang berakhir dengan penandatanganan BATB dan penetapan resmi sebagai Hutan Negara oleh Surat Keputusan Menteri Kehutanan.

\section{Implikasi dan Kesimpulan}

Kami menemukan tidak adanya dasar hukum atas praktek sistem ganda kewenangan atas penguasaan tanah. Setelah meninjau berbagai peraturan perundangan sektoral yang relevan dan kerangka hukum Indonesia, kami menyimpulkan bahwa ada pandangan yang kuat bahwa dasar hukum atas penguasaan semua tanah, termasuk kawasan hutan yang telah sepenuhnya ditetapkan sebagai kawasan hutan negara, tetap berada di bawah kewenangan BPN. Sedangkan penggunaan dan pengelolaan hutan secara keseluruhan merupakan tanggung jawab dari Departemen Kehutanan. Otoritas atas pengelolaan hutan meliputi 120 juta hektar yang ditetapkan sebagai Kawasan Hutan harus tetap di negosiasikan dengan perencanaan tata ruang daerah namun apabila menjadi kawasan hutan, kewenangan atas penguasaan tanahnya bukan menjadi kewenangan Departemen Kehutanan.

Seperti yang dikemukakan sebelumnya, implikasi dari hal ini jauh ke depan. Hal yang paling mendesak menyangkut penerbitan ijin-ijin Pengusahaan Hutan dalam bentuk HPH dan HTI. Walaupun Departemen Kehutanan mempunyai otoritas untuk menerbitkan ijin $\mathrm{HPH}$, akan tetapi masih merupakan tanda tanya apakah secara hukum hal ini dapat dilakukan atas kawasan hutan yang belum sepenuhnya ditetapkan. Tampaknya hal tersebut juga berlaku pada penerbitan ijin HTI, sebagaimana ijin HTI merupakan ijin penggunaan lahan dan bukan izin explotasi hutan.

Hal ini menimbulkan pertanyaan apakah Departemen Kehutanan telah melewati batasan kewenangannya atas perlakuan defacto mereka pada keseluruhan Kawasan Hutan dan memperlakukannya sebagai Kawasan Hutan Negara, ketika tidak ada dasar dejure untuk melakukan hal itu.

$\mathrm{Hal}$ ini juga menimbulkan kesempatan-kesempatan baru bagi kedua pihak, Dephut dan BPN untuk menegaskan kembali perannya dan menegaskan hubungan kerjasama mereka. Dari kedua lembaga tersebut, sangat jelas bahwa kebutuhan untuk meninjau kembali peran Departemen Kehutanan sangatlah mendesak, baik dalam konteks kewenangan pengaturan maupun dalam kewenangan pengurusan hutan (forest governance) secara keseluruhan. 
Akhir kata, kami menyajikan analisa ini dengan maksud untuk merangsang diskusi hukum yang lebih luas mengenai pertanyaan penting ini dan bukan sebagai pernyataan tetap (definitive statement) tentang hal ini.

\section{DAFTAR PUSTAKA}

Badan Planologi Kehutanan, 2003. Pengelolan Pembangunan Kehutanan \& Perkebunan yang Selaras dengan Proses Desentralisasi dan Penerapan Prisnsip prinsip Good Governance ditinjau dari Aspek Koordionasi Penyusunan Kebijakan, 14-15 Oktober 2003 Pekan Baru.

Boedi Harsono, 1997 Hukum Agraria Indonesia; Sejarah Pembentukan UUPA, Isi dan Pelaksanaannya, jilid 1, cetakan ke 8, Djambatan, Jakarta.

Brown David, 2003. Edicted to Rent. Jakarta.

Colchester Marcus, Sirait Martua \& Widjarjo Boedhi 2003. The Application of FSC Principles 2 \& 3 in Indonesia; Obstacles \& Possibilities, Walhi, 2003 Jakarta.

de Jong Wil, Van Noordwijk Meine, Sirait Martua, Liswanti Nining \& Suyanto. Farming the Secondary Forest. Paper prepared for the Secondary Forest Seminar, CIFOR-GTZ 2000. Samarinda. Published in Malaysian Forestry Journal, Penang 2002.

Dephut-Dinas Kehutanan Kab. Garut 2004, Laporan Operasi Jagawana Kab Garut 2004;
Departemen Kehutanan 2003. Statistik Kehutanan 2002. Dephut, Jakarta.

Departemen Kehutanan 2004. Statistik Kehutanan 2003, Dephut, Jakarta.

Fay Chip \& Sirait Martua 2000, Reforming the Reformist, in Which Way Forward? People and Policy Making in Indonesia, Carol Colfer \& Ida Aju Pradnja Resosudarmo ed. Resource For the Future, Washington

Fay Chip \& Sirait Martua, Apakah Dampak Lingkungan system Wanatani? Perdebatan Fungsi Publik dan Privat, Wanatani yang dikelola oleh rakyat, dalam Wanatani di Nusa Tenggara. Prosiding Lokakarya Wanatani se Nusa Tenggara, 11-14 November 2001, Denpasar Bali. ICRAFWINROCK INTERNATIONAL. 2002

Fern 2001, Forest Fear:The Abuse of Human Rights in Forest Conflict;

Foresta, Kusworo, Michon, Djatmiko 2000, Ketika Kebun berupa hutan: Sebuah Sumbangan masyarakat, ICRAF Bogor

Jurnal Hutan Rakyat 2002, Sustensi Hutan Rakyat dan Pengelolaan DAS, Pustaka Hutan Rakyat Vol IV, no 3, Yogyakarta

Kusworo Ahmad, 2000 Perambah Hutan Atau Kambing Hitam? Potret Sengketa Kawasan Hutan di Lampung, ICRAF-IRD-WATALA, Pustaka Latin , Bogor

Litski Josef 2004, Forest Products: Fact Sheet 8, September 2004

Peluso Nancy L, 1992. Rich Forest Poor People. New Haven, New York 
Roshetko, Mulawarman, Santosa, Oka (ed) 2002 Wanatani di Nusatenggara, ICRAF-Winrock, Bogor

Sirait Martua, Prasodjo Sukirno, Podger Nancy , Flavelle Alex \& Fox Jefferson1994. Mapping Costumary Land in East Kalimantan; A tool for forest management. Journal of the Human Environment AMBIO. Vol XXIII no. 7 November 1994. The Royal Swedish Academy of Science, Sweden.

Sirait Martua \& Moniaga Sandra, Sejarah Pemetaan Masyarakat dan Partisipasi Politik, Kabar JKPP, No I, 1997, Bogor.

Sirait Martua \& Ruwijanto A. Proses Penetapan Kawasan Hutan Negara di Indonesia, TELAPAK Sirkular no. 1, 1998, Bogor.

Sirait Martua, Situmorang Lisken, Pengukuhan Hutan dan Reforma Penguasaan Tanah.. Paper presented during the JKPP Conference 2 April 2003, Cisarua West Java

Sirait Martua, Situmorang Lisken, Galudra Gamma, Fay Chip \& Pasya Gamal, 2004 Kebijakan Pengukuhan Kawasan Hutan dan Realisasinya. ICRAF-SEA Working Paper, No.2004_2, Bogor

Sirait Martua, Don Bosco Bulor, Yoga Sofyar, Dwi Anugrah, Ratna Rismawan \& Didin Suryadin. Kilip Journey to Seek Recognition: Reflection from the Development of Participatory Methodology of Identifying Adat Communities in Kutai Barat District, East Kalimantan. Paper Presented during the International Tenure
Conference on Indonesia; Questioning the Answers, 11-13 October 2004, Jakarta.

Sumardjono Maria, 2001. Kebijakan Pertanahan antara Regulasi \& Implementasi, Kompas, Jakarta.

Sumardjono Maria, 2003 Penyempurnaan UUPA dan Sinkronisasi Kebijakan. SKH KOMPAS, Rabu 24 September 2003.

Sumardjono Maria, 2004a. Kedudukan Hak Ulayat dan Pengaturannya Dalam Berbagai Peraturan Perundang Undangan. dipresentasikan dalam berbagai seminar ditahun 2004.

Sumardjono Maria, 2004b. Kriteria Eksistensi Hak Ulayat. Paper disampaikan pada semiloka "perlindungan dan Pemajuan Hak Asasi Masyarakat Hukum Adat", KOMNAS HAM-AIPI, 14 Desember 2004.

Suhardjito (ed), 2000, Hutan Rakyat di Jawa; Peranannya dalam Ekonomi Desa, Fahutan IPB, Bogor;

Sukanti Arie Hutagalung, Prof, 2003 Konsepsi yang mendasari Penyempurnaan Hukum Tanah Nasional, Universitas Indonesia, Jakarta.

Tari Dala \& Adi Jaya, 2002, Pranata Hutan Rakyat, Pustaka Kehutanan Masyarakat, Debut, Yogyakarta.

Thornburn Craig 2002, The Plot Thickens; Decentralisation and Land Administration in Indonesia. 
UGM 2003, Penjabaran Prinsip Prisnip

TAP MPR IX/2001 dan Upaya Harmoinisasi Peraturan

Perundang-Undangan di Bidang Sumber Daya Agraria. UGM, 14 November 2003 Yogyakarta.

Warsi 2000, Ketika Rakyat Mengelola Hutan; Pengalaman dari Jambi, Pustaka SHK, Bogor.

World Agroforestry Center 2003, Towards Rationalization of Forest Areas. Working Paper 2003, Bogor. 